\title{
Disaster book
}

Forces of Nature. Edited by Sir Vivian Fuchs. Pp. 303. (Thames and Hudson: London, 1977.) £9.50.

Perhaps unwittingly, this book plays a small part in a curious paradox. For the past few years the world economy has been in recession, human institutions have been under threat as seldom before, and the general feeling has been one of gloom and despondency. But as if that were not enough, the same period has seen a remarkable upsurge in the publication of books about those macroscopic forces of nature which can, and do, contribute to recession, destroy human institutions and give rise to gloom, not to mention real hardship. The level of interest in earthquakes, volcanic eruptions, drought, floods, avalanches, tornadoes and forthcoming ice ages has recently reached a new height and shows no sign of falling. It is almost as if we were trying subconsciously to diminish the relative force of human mismanagement by pointing to greater events beyond our control.

But if so, we are doomed to failure, for what Sir Vivian's book tells us time and again is that in the face of disruptive natural forces human folly is only magnified. The ancient city of Antioch was repeatedly destroyed by earthquakes and equally repeatedly rebuilt on the same site with similar materials and no more effective rules-a self-defeating activity which even the most highly developed nations have been unable to avoid. In 1963 the Vaiont reservoir in Italy overflowed violently with the loss of 2,600 lives, because no-one had read the lessons plainly visible in the local history of landslides. In Switzerland the obvious dangers of avalanche are often ignored even by experienced mountaineers. In countries where drought is endemic, populations grow unchecked, making each disaster more devastating than the last. And so on.

Under the circumstances it is perhaps understandable that Sir Vivian should take a dim view of human capability. Of all the forces of nature, he suggests in his introduction, "none can be controlled by human agency. Even if our growing knowledge was to make this possible, it is doubtful if we have, or could acquire, the wisdom to handle them for the general good .. . It may well be wiser to accept the broad interplay of natural forces, always learning better how to use them or to protect ourselves from them." Not everyone would agree with that, regarding it as overly defeatist, for the reference to protection reminds us that man is not entirely incapable of fighting nature. From the Tennessee Valley Authority (for all its faults), through splitting wedges in the Alps and the sea wall at Skegness, to the person who decides that Denver offers a safer life than Los Angeles, there is ample evidence that nature needed not always win.

In Forces of Nature, each chapter of which is written by "an expert in his field", man's attitudes and responses to natural phenomena are given more than usual attention, although firmly set against a background of scientific explanation. The blend of science and sociology works well, leading to a nicely balanced text that should have wide appeal. What ultimately makes the book, however, is less the text than the remarkable collec- tion of photographs (researched by Sarah Waters), some in black-andwhite but many in colour.

And therein lies something slightly unnerving. For the truth is that in the hands of a brilliant photographer, and with a magnificent standard of reproduction, the consequences of the most devastating natural disaster may be recorded as something of astonishing beauty. The funnel of a tornado crossing Oklahoma, a parched and droughtcracked river bed in Kenya, rooftops projecting from a major flood near Brisbane, the distortion of a flood-swept railway line in the Netherlands, and molten lava from Etna advancing towards civilisation, must all have represented absolute despair to someone; and yet on the page they make pictures as enticing in their way as a Hay Wain or a Fighting Temeraire. It's all vaguely disconcerting, but makes for a fascinating book.

Peter J. Smith is Reader in Earth Sciences at the Open University, Milton Keynes, UK.

\section{Time problems in land processes}

Geomorphology and Time. By J. B. Thornes and D. Brunsden. Pp. 208. (Methuen: London, 1977.) Hardback $£ 6$; paperback $£ 3.45$.

What George Poulett Scrope wrote in 1858 , that "the leading idea which is present in all our researches, and which accompanies every fresh observation, the sound which to the ear of the student of Nature seems continually echoed from every part of her works, is-Time! . . . Time! . . . Time!", cculd be equally well be applied to studies today. It was the geologist who discredited the rigid biblical timescale and extended the overall limits of earthly time from under 6,000 years to over 4,000 Myr. Geomorphologists joined the geological bandwagon with one hand on the leading rein. Quite early they began to be interested in rates of processes, and eventually acquired an assortment of morphological measurements and crude timescales for the effects of denudation and deposition on landforms.

Being concerned with present processes, geomorphology has contemporary utility, and the hope has always been that the present would also provide a key to the past. This is of course, true of the action of processes and untrue of landscapes. In any event, time-independent processes cannot exist. So time is a necessary ingredient of geomorphological research and must be considered with other essential features such as lithology, process and spatial variability, all of which impinge on problems of scientific observation, model-building and interpretations of the temporal occurrence of events.

The authors of this book elucidate these ideas on time in a lively introduction which treads warily around many pitfalls and will stimulate much thought. For example, we are told that velocity is expressed as distance moved in unit time $(L / T)$. This seems reason- 